nial Training Schools, Gray's-inn-road. The eruption consisted of papulæ, with only a few characteristic vesicles here and there dispersed, and attended with very slight indisposition, the eruption drying off within a week. Separation of the subjects of this slight epidemic was enjoined.

On November 29th my attention was called to M. R--, aged eighteen. She complained of universal malaise, of the rheumatalgic kind. On Dec. 4th numerous papulæ appeared on the face and hands, which spread over the whole surface. On the ninth day they became vesicular, filled with strawcoloured fiuid, and confluent, first on the wrists and back of the hands, then on the face and forehead, forming a complete mask. The eruption-first papular, then vesicular, but never purulent-was distinct but very numerous, over the whole surface, and many vesicles occupied the tongue and fauces. Although the eruption was so formidable, the eruptive fever and the secondary or fever of maturation were comparatively mild. On the fourteenth day the vesicles began to dry off in flakes on the wrists and face, leaving only a redness, no cicatrices; and on the rest of the surface in round scabs, without the slightest approach to the umbilicated crusts of variola. It appeared simply as a cutaneous eruption, which did not extend to the basement or subareolar tissue, and therefore it gave rise to only very slight pitting.

The case was seen by my friond Dr. Bealey, of Tavistocksquare, who at once fully confirmed my diagnosis. He had never seen a case of the kind before; and I only one, that I recollect, twenty years ago, which came under my care at the same institution.

The treatment was very simple: an aperient in the papular, and again in the vesicular, febrile stage; effervescing citrate of potass; a darkened, airy room; a cool regimen; painting the face with flexible collodion to prevent the possibility of cicatrices. The diet consisted of apple-tea, barley and gum. water flavoured with lemon-peel; corn-flour, arrowroot, and milk; custard pudding during the febrile or eruptive stage. Then chicken-broth and chicken during desquamation and convalescence. She really had not an untoward symptom from the commencement to the termination of this apparently appalling, but in reality mild, disease.

Montague-street, Feb. 1868.

\section{PARALYSIS OF THE FEMALE BLADDER AFTER DELIVERY, CURED BY THE INTERNAL APPLICATION OF ELECTRICITY.}

\section{BY W. H. TAYLER, M.D.}

I LATELY attended a patient, aged thirty-five, in her first eonfinement. The labour was a very tedious one, and eventually I had to deliver with the forceps, which, owing to the smallness of the pelvis, was a maitter of some difficulty. The child was, however, born alive. There was no injury to the soft parts; but the patient was unable to pass any urine, saying she seemed to have lost feeling, and had not any power to evacuate the bladder. I passed the catheter twice daily for some days, and adopted the usual remedies, without any result in improving the tone of the bladder. I therefore resolved to try the effect of electricity to the internal surface of the blad. der, having lately purchased of Mayer one of Dr. Mackenzie's laryngeal electrodes. I saw it would be a most convenient instrument to use in this case; so having attached to it a magneto-electric machine, I passed the instrument into the bladder, and applied the electric current for about five minutes, completing the circuit by passing the other handle of the machine over the pubic region and sacrum. After two applications (the bladder being previously emptied) there was a slight improvement. On the third application I introduced the electrode before using the catheter, and under the influence of the electric current the bladder forced the urine out by the side of the instrument, and on the same day the patient was able to pass urine. I applied it again for the fourth time on the following day on the emptied bladder, after which the patient had full control over the bladder, and continues to pass her urine without any difficulty, and is doing well in every respect.

Tudor House, Anerley, Febrnary, 1863.

The Hospital for Consumption has become entitled to $£ 1000$ under the will of Henry Blundell, Esq., of Devonshire-place, Balham, Surrey.

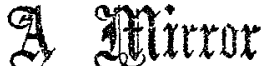

OF THE PRACTICE OF

\section{MEDICINE AND SURGERY}

IN THE

\section{HOSPITALS OF LONDON.} Nulla autem est alia pro certo noscendi via, nisi quamplurimas et morborum
of dissectionum historias, tum aliorum, tum proprias collectas habere, et inter se comparare.-Morgaki Do Sed. et Caus. Morb., lib. iv. Procemium.

\section{UNIVERSITY COLLEGE HOSPITAL.}

LONG-CONTINUED SYPHILIS; TRANSMISSION OF THE DISEASE TO TWO CHILDREN ; ULCERATED TONGUE CURED BY PROLONGED MERCURIAL COURSE.

(Under the care of Mr. Berkeley HILL.)

Tre following history, which extends over several years, gives a striking example at once of the obstinacy of syphilis, and the marked influence produced upon it from time to time by the administration of mercury. The account is, besides, of special interest in reference to the condition of the patient's children, who presented most characteristic marks of the inherited disorder. We publish it in more than usual detail, because it furnishes incidentally numerous hints as to the diagnosis and treatment of constitutional syphilis.

J. L_- aged thirty-nine, married sixteen years. According to her account three months after marriage she caught a violent cold. This was soon followed by ulceration of the tongue and throat; the latter got better, but not the tongue, which has been more or less diseased ever since. At the outset she took much sarsaparilla, but probably no mercury at that time. Including four miscarriages, she has had nine pregnancies. Two children are living; of the rest, one died of heart disease when ten and a half years old, another at birth, and four years ago, a third, the last, was born dead. She believes she has never lad a primary syphilitic sore, breakings out on the skin, or other signs of syphilis. She has taken a great quantity of mercury to try to cure her tongue, but hitherto in vain.

At the time of first observation, November, 1864, the tongue was much swollen, its upper surface marked with white patches, and deeply divided by sinuous fissures, which gave it a chequered appearance. There was much thickening and ulceration at the sides, especially on the left, to ease the chafing of which against the teeth, she had once a molar tooth drawn. Her health had been tolerably good, her chief ailments having been this disorder of the tongue and repeated miscarriages. She looked fairly robust, and had no syphilitic aspect. She was ordered a quarter of a grain of bichloride of mercury, four grains of iodide of potassium, and an ounce of infusion of ouassia twice a day, and to use a gargle of hydrochloric acid and alum irequently. After taking this medicine a week, the tongue looked and felt much better.

Nov. 16th. - An ulcer has appeared on the lining membrane of the septum narium, for which an ointment of natric oxide of mercury was ordered, and it is very nearly well. The tongue is better. The gums are very slightly spongy, and a little tender. Mixture and gargle repeated.

30th.-Tongue less painful; not so much swollen. The patient feels altogether better. Medicine changed to oneeighth of a grain of bichloride of mercury, four minims of dilute bydrochloric acid, one ounce quinine mixture, three times a day.

Dec. 7 th.-Tongue worse to-day. There is a large white patch on the upper surface on the left side. The ulcers of the left edge are rather more prominent.

17 th. - Tongue much better; the large white patch still remains. Other smaller patches are now searcely visible.

Jan. 18th, 1865. - The tongue is more shining and brighter; it causes less pain when moved. Numerous small aphthouslooking spots are visible on the roof of the mouth.

25th. - All the patches except the large one have disappeared. The roof of the mouth is better. As the gums are not much affected, the dose of bichloride of mercury to be changed from an eighth to a fifth of a grain.

Feb. 1st.-Tongue much better; the ulcers on the right side 